\title{
Review Article \\ Interpretation of C-Reactive Protein Concentrations in Critically Ill Patients
}

\author{
Christophe Lelubre, ${ }^{1,2}$ Sophie Anselin, ${ }^{1}$ Karim Zouaoui Boudjeltia, \\ Patrick Biston, ${ }^{1}$ and Michaël Piagnerelli ${ }^{1,2}$ \\ ${ }^{1}$ Department of Intensive Care, CHU-Charleroi, Université Libre de Bruxelles, 92 Boulevard Janson, 6000 Charleroi, Belgium \\ ${ }^{2}$ Experimental Medicine Laboratory, CHU-Charleroi, ULB 222 Unit, 6110 Montigny-Le-Tilleul, Belgium
}

Correspondence should be addressed to Michaël Piagnerelli; michael.piagnerelli@chu-charleroi.be

Received 6 April 2013; Accepted 4 September 2013

Academic Editor: Anthony Gerlach

Copyright ( 2013 Christophe Lelubre et al. This is an open access article distributed under the Creative Commons Attribution License, which permits unrestricted use, distribution, and reproduction in any medium, provided the original work is properly cited.

\begin{abstract}
Infection is often difficult to recognize in critically ill patients because of the marked coexisting inflammatory process. Lack of early recognition prevents timely resuscitation and effective antimicrobial therapy, resulting in increased morbidity and mortality. Measurement of a biomarker, such as C-reactive protein (CRP) concentration, in addition to history and physical signs, could facilitate diagnosis. Although frequently measured in clinical practice, few studies have reported on the pathophysiological role of this biomarker and its predictive value in critically ill patients. In this review, we discuss the pathophysiological role of CRP and its potential interpretation in the inflammatory processes observed in critically ill patients.
\end{abstract}

\section{Introduction}

Sepsis, defined as an intense immune reaction occurring as a result of the presence of a pathogen in the organism, is frequent in critically ill patients and is associated with high morbidity and mortality $[1,2]$. Recognition and early therapy are the cornerstones of management $[3,4]$. When the diagnostic probability of sepsis is high (e.g., a patient with bacteremia complicated by shock and multiple organ failure), measurement of a biological marker (a biomarker) is not really necessary before starting appropriate treatment. However, when a diagnosis of sepsis is less obvious, biomarkers may be more relevant, especially if measurement of the biomarker is rapid and cheap, and results have high specificity and sensitivity for sepsis. Of course, the biomarker result should not be the only trigger for a decision to treat or not, but should be combined with the presence of clinical signs suggesting infection [5]. In this setting, plasma Creactive protein (CRP) measurements are frequently used as a biomarker.

In this paper, we will briefly review the biochemistry of CRP and its known (patho) physiological roles. As a biomarker for critically ill patients, we discuss its value at intensive care (ICU) admission and its time course during inflammatory states, such as those observed in septic patients. Finally, we describe its pertinence in two particular types of infection: pneumonia and hepatic failure. The role of CRP as a biomarker for cardiovascular disease is not described here and was reviewed recently [6].

\section{Biochemical Characteristics of CRP}

As a serum amyloid $\mathrm{P}$ component, CRP belongs to the pentraxin family of calcium-dependent ligand-binding plasma proteins. This family is highly conserved during evolution.

Human CRP is composed of five identical, nonglycosylated polypeptide subunits, each composed of 206 amino acid residues [7]. These subunits are noncovalently associated in an annular configuration with cyclic pentameric symmetry. The binding site of CRP is composed of subunits with 2 calcium ions, located on the concave face of the protein [7].

Recently, monomeric CRP, resulting from the loss of its pentameric symmetry, has been described; this form probably has greater prothrombotic properties [8]. 


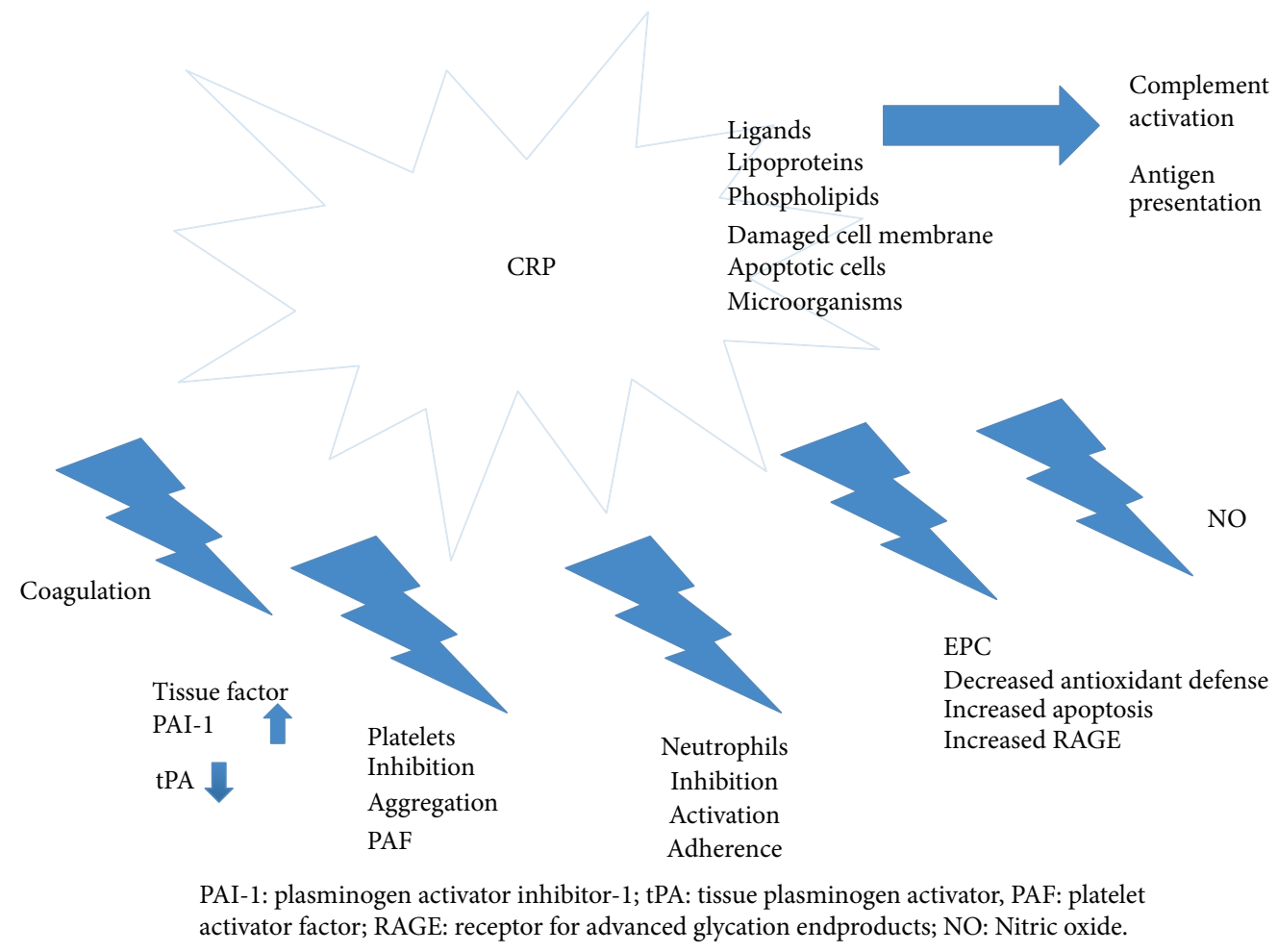

FIGURE 1: Summary of the principal physiological roles of C-reactive protein.

\section{Synthesis of CRP}

CRP was first discovered by Tillet and Francis in 1930 in the sera of patients with Streptococcus pneumoniae pneumonia and was called the "fraction C protein" [9]. At that time, CRP was considered as a marker of infection because the onset of the precipitation reaction observed with the sera of these patients was largest when they were critically ill [9].

In healthy Caucasian volunteers, median serum concentrations of CRP, as assessed by solid phase radioimmunoassay, were reported to be $0.8 \mathrm{mg} / \mathrm{L}$ (interquartiles 0.34 to $1.7 \mathrm{mg} / \mathrm{L}$ ) [10], although some of the differences in reference values may have been related to ethnic subgroups [11]. Approximately $50 \%$ of the individual variation in physiologic CRP concentrations is genetically attributable to noncoding polymorphisms in the CRP gene, located on chromosome 1.

CRP is a positive acute phase protein produced by the liver in response to stimulation by interleukin (IL)-6. Serum concentrations can increase by up to 1000 -fold in inflammation, as compared to physiologic concentrations. Whereas proinflammatory cytokines (e.g., IL-1, IL-6, and tumor necrosis factor $\alpha$-[TNF- $\alpha]$ ) appear within one hour after the start of bacterial infection, and procalcitonin (PCT) after 5 hours, the hepatic synthesis of CRP starts 6 to 8 hours after onset [12] and peak concentrations are reached between 36 to 50 hours after infection has started. The halflife of CRP is 19 hours [13] and it is cleared by the liver. Although extrahepatic CRP synthesis has been reported in neurons [14], atherosclerotic plaques [15], lymphocytes [16], and adipocytes [17], this synthesis has very little impact on serum concentrations. This local production of CRP may be a process of localized inflammation and a marker for local cellular damage $[14,17]$.

\section{Physiologic Roles of CRP}

The physiological roles of CRP are summarized in Figure 1. Even though CRP has been known for more than 80 years [9], its exact physiological roles remain largely unknown. Before describing current knowledge regarding the anti- and proinflammatory roles of CRP, it is important to remember that it may not always be possible to directly extrapolate results obtained in animal models to the clinical situation in humans. Indeed, although CRP has been highly conserved during evolution, the time course of CRP synthesis is related to the species. For example, in mice, the most frequently used animal model, CRP concentrations only increase slightly during the acute phase response. Moreover, considerable variations between species are observed with respect to ligand-binding specificity and glycosylation status [7].

4.1. Activation of the Complement Pathway. Globally, the biological role of CRP after binding to ligands is to trigger the complement pathway [7] CRP binds with greatest affinity to phosphocholine residues, and with less affinity to native and modified lipoproteins [44], damaged cell membranes, a number of phospholipids, small nuclear ribonucleoprotein particles, and apoptotic cells [45]. It also binds constituents of microorganisms (compounds of the membranes of bacteria, 
fungi, parasites, and plants) and facilitates antigen presentation on dendritic cells [46]. When aggregated or bound to macromolecular ligands, CRP is recognized by complement protein $\mathrm{Clq}$ and potently activates the classical complement pathway, engaging C3, the main molecule of adhesion of the complement system, and the terminal membrane attack complex (C5-C9) [47]. Bound CRP may also provide secondary binding sites for factor $\mathrm{H}$ and, thereby, regulate alternativepathway amplification and C5 convertase $[48,49]$.

4.2. Antiinflammatory Effects of CRP. In vitro, the antiinflammatory effects of CRP are the result of inhibition of neutrophil activation, adherence, and trafficking into tissues [50]. CRP may decrease the production of cytokines and the expression of adhesion molecules (intercellular adhesion molecule (ICAM) 1, E and P selectins) [51]. CRP inhibits phospholipases and platelet-activating factor (PAF), protecting the platelet membrane and decreasing the aggregation process [8].

In vivo, the antiinflammatory effects are illustrated by the study of Xia and Samols [50] in which mortality rates in transgenic mice overexpressing CRP (CRP concentrations between $75-200 \mathrm{mcg} / \mathrm{mL}$ ) decreased after injection of lipopolysaccharide (LPS) or other proinflammatory mediators, such as PAF or TNF- $\alpha$, compared to CRP-deficient mice (CRP concentrations $<20 \mathrm{mcg} / \mathrm{mL}$ ) [50].

4.3. Proinflammatory Effects of CRP. CRP also has a proinflammatory role. When recombinant CRP is incubated with endothelial cells from the aorta, multiple genes for proinflammatory proteins, such as IL-8, fibronectin, and plasminogen activator inhibitor 1 (PAI-1), are expressed [52]. These results must be interpreted with regard to the in vitro model and the type of endothelial cells studied [52]. In a mouse model, Hirschfield et al. [53] observed no protective effects of recombinant human CRP injection after LPS challenge, in contrast to the study by Xia and Samols [50]. The contrasting results of these two studies $[50,53]$ highlight the difficulties associated with extrapolating results from one model to another.

4.4. CRP in Coagulation and Fibrinolysis. CRP may be the link between inflammation and coagulation in sepsis [13]. Indeed, CRP contributes to a prothrombotic state by the liberation of tissue factor (TF) by monocytes [54], endothelial cells, and smooth skeletal muscle cells [55]. The in vitro study by Wang et al. [52] showed increased expression of the gene for PAI-1 in cells incubated with CRP, and decreased activity of tissue plasminogen activator (tPA) has also been observed [55]. All of these effects may lead to an imbalance in the fibrinolytic system [56]. A study performed in healthy volunteers confirmed these results [57]; after injection of recombinant CRP, there was an increase in fibrinolysis, as suggested by increased concentrations of the prothrombotic fragments, $\mathrm{F} 1+\mathrm{F} 2$, and D-dimers. Identical results were observed in hypercholesterolemic patients [58]. However, these studies demonstrating procoagulant effects of CRP have been criticized due to the possibility of endotoxin contamination and need confirmation [59]. Nevertheless, in 32 critically ill patients with and without sepsis, we observed a significant correlation $\left(r^{2}=0.45, P<0.001\right)$ between CRP concentrations at ICU admission and fibrinolysis assessed by the euglobulin lysis test [60].

4.5. CRP and the Nitric Oxide (NO) Pathway. CRP may also modulate NO bioavailability and NO synthase (NOS) expression. This effect on NO production remains controversial due to the different models studied (animals or in vitro). In transgenic mice expressing human CRP, Grad et al. [61] observed that NOS and NO expressions were locally and systematically suppressed after arterial femoral injury. In contrast, Clapp et al. [62] observed increased NO reactivity with no change in NOS activity after incubation of rat aorta with purified CRP. The observed vasodilatory effect was not due to the NO itself but more likely the result of increased expression of GTP cyclohydrolase-1, the rate-limiting enzyme in the synthesis of tetrahydrobiopterin, the NOS cofactor [62]. In several studies involving endothelial progenitor cells, CRP was shown to decrease endothelial NO production, decrease antioxidant defenses of the cells, increase expression of the receptor for advanced glycation end-products (RAGE), and induce apoptosis of endothelial cells $[63,64]$.

\section{CRP Concentrations as a Biomarker of Infection in Septic Patients}

Sepsis remains an important cause of mortality in the ICU $[1,3,4]$ and delay in appropriate antibiotherapy may increase morbidity and mortality in septic patients [65]. Because of wide availability, good reproductibility, and low cost, CRP concentrations could be an attractive biomarker [66]. Questions remain regarding the predictive value, sensitivity, and specificity of CRP to diagnose infection in ICU patients, especially in patients receiving specific treatments (e.g., glucocorticoids $[67,68]$ or statins [69]). The various studies performed in ICU patients are summarized in Table 1. Ugarte et al. [18] measured CRP and PCT concentrations in 180 critically ill patients with $(n=111)$ and without infection $(n=$ 79). Surgical patients and patients in whom there was a doubt regarding the presence of infection (antibiotherapy without bacteriological proof) were excluded. The median CRP value was significantly higher in infected patients (12.1 versus $5.6 \mathrm{mg} / \mathrm{dL}$ ), with a best cut-off value of $7.9 \mathrm{mg} / \mathrm{dL}$. However, on admission, $33 \%$ of the noninfected patients had CRP concentrations greater than $7.9 \mathrm{mg} / \mathrm{dL}$, making it difficult to discriminate patients with and without infection based on this CRP measurement. Similarly, in 74 ICU patients, Reny et al. [19] observed that CRP values were more elevated in patients with proven infection $(n=28)$ compared to those without $(191 \pm 123$ versus $83 \pm 91 \mathrm{mg} / \mathrm{L}, P<$ $0.0001)$. No threshold for CRP was identified to discriminate between infected and noninfected patients. The change in CRP concentration between admission and day 4 was the best predictor for recovery [19].

Póvoa et al. [20] also studied CRP concentrations at ICU admission as a marker of infection. In 112 patients, these 
TABLE 1: Summary of the studies in critically ill patients.

\begin{tabular}{|c|c|c|c|}
\hline Studies & Types of patients included & Conclusions & Remarks \\
\hline Ugarte et al. [18] & $\begin{array}{l}180 \text { patients with } \\
(n=111) \text { and without infections } \\
(n=79) .\end{array}$ & $\begin{array}{l}\text { Best cut-off value } \\
\text { for CRP levels for diagnosis of } \\
\text { infection was } 7.9 \mathrm{mg} / \mathrm{dL}\end{array}$ & Exclusion of surgical patients \\
\hline Reny et al. [19] & $\begin{array}{l}74 \text { patients with } 28 \text { with proven } \\
\text { infection }\end{array}$ & $\begin{array}{l}\text { Higher CRP concentrations in } \\
\text { infected patients }\end{array}$ & $\begin{array}{l}\text { (i) No cut-off value for CRP } \\
\text { (ii) Evolution of CRP between } \\
\text { admission and day } 4 \text { was related to } \\
\text { outcome }\end{array}$ \\
\hline Póvoa et al. [20] & $\begin{array}{l}\text { Subgroup of patients with VAP } \\
(n=48)\end{array}$ & $\begin{array}{l}\text { Higher CRP levels in patients with } \\
\text { VAP than in noninfected patients. }\end{array}$ & $\begin{array}{l}\text { No CRP comparisons between } \\
\text { patients with VAP and other } \\
\text { infections }\end{array}$ \\
\hline Póvoa et al. [21] & $\begin{array}{l}\text { Patients with a length of stay } \geq 3 \\
\text { days }\end{array}$ & $\begin{array}{l}\text { A maximum daily variation of } \\
4.1 \mathrm{mg} / \mathrm{dL} \text { is a good marker of } \\
\text { infection }\end{array}$ & $\begin{array}{l}\text { Long delay between positive culture } \\
\text { and start of antibiotics }\end{array}$ \\
\hline Lobo et al. [22] & $\begin{array}{l}303 \text { patients with a length of stay } \geq 2 \\
\text { days }\end{array}$ & $\begin{array}{l}\text { (i) High CRP at admission was } \\
\text { associated with higher risk of } \\
\text { infection } \\
\text { (ii) Daily increase in CRP was } \\
\text { associated with mortality }\end{array}$ & $\begin{array}{l}\text { Results only applicable if CRP at } \\
\text { admission is }>10 \mathrm{mg} / \mathrm{dL}\end{array}$ \\
\hline $\begin{array}{l}\text { Castelli et al. } \\
{[23]}\end{array}$ & $\begin{array}{l}255 \text { patients (111 septic, } 49 \text { trauma, } \\
45 \text { with, and } 50 \text { without SIRS) }\end{array}$ & $\begin{array}{l}\text { (i) Cut-off for infection: } 128 \mathrm{mg} / \mathrm{L} \\
\text { (ii) Higher values in relation to the } \\
\text { severity of sepsis }\end{array}$ & $\begin{array}{l}\text { Maximum CRP with a delay of } 24 \\
\text { or } 48 \text { hours }\end{array}$ \\
\hline $\begin{array}{l}\text { Silvestre et al. } \\
{[24]}\end{array}$ & 158 ICU patients & $\begin{array}{l}\text { No relationship between CRP at } \\
\text { ICU admission and infection and } \\
\text { mortality }\end{array}$ & $\begin{array}{l}\text { No relationship between CRP and } \\
\text { presence of a microorganism }\end{array}$ \\
\hline
\end{tabular}

\begin{tabular}{|c|c|c|c|}
\hline & & mortality & \\
\hline Póvoa et al. [25] & $\begin{array}{l}891 \text { patients admitted in ICU with } \\
\text { diagnosis of community-acquired } \\
\text { sepsis. } \\
\text { Follow-up of } 5 \text { days }\end{array}$ & $\begin{array}{l}\text { (i) No difference in CRP at ICU } \\
\text { admission between survivors or } \\
\text { nonsurvivors } \\
\text { (ii) No decrease in CRP at day } 3 \text { was } \\
\text { associated with a poor outcome }\end{array}$ & $\begin{array}{l}\text { Same evolution for SOFA score but } \\
\text { not for fever or leukocyte count }\end{array}$ \\
\hline $\begin{array}{l}\text { Vandijck et al. } \\
{[26]}\end{array}$ & $\begin{array}{l}84 \text { ICU patients with nosocomial } \\
\text { bacteremia }\end{array}$ & $\begin{array}{l}\text { Higher values of CRP with } \\
\text { Gram-negative bacilli compared to } \\
\text { Gram-positive cocci bacteremia }\end{array}$ & $\begin{array}{l}\text { Review of the time course of CRP } \\
\text { before the bacteremia } \\
\text { Predictive factor? }\end{array}$ \\
\hline Póvoa et al. [27] & $44 \mathrm{ICU}$ patients with bacteremia & $\begin{array}{l}\text { CRP concentrations ratio start to } \\
\text { change only at day } 2 \text { in survivors. }\end{array}$ & $\begin{array}{l}\text { CRP ratio only predictive of } \\
\text { outcome at day } 4\end{array}$ \\
\hline $\begin{array}{l}\text { Zhang and } \mathrm{Ni} \\
{[28]}\end{array}$ & $\begin{array}{l}\text { Meta-analysis of } 14 \text { studies } \\
\text { including } 1969 \text { patients }\end{array}$ & $\begin{array}{l}\text { Evolution of CRP for more than } 48 \\
\text { hours is predictive of outcome }\end{array}$ & $\begin{array}{l}\text { Large heterogeneity of the studies } \\
\left(I^{2}=92 \%\right)\end{array}$ \\
\hline Póvoa et al. [29] & $\begin{array}{l}186 \text { septic cancer patients with } \\
(n=86) \text { or without }(n=68) \\
\text { neutropenia }\end{array}$ & $\begin{array}{l}\text { (i) CRP concentrations were higher } \\
\text { in neutropenic patients } \\
\text { (ii) No relation with the severity of } \\
\text { the neutropenia }\end{array}$ & $\begin{array}{l}\text { Same evolution of CRP between } \\
\text { neutropenic and nonneutropenic } \\
\text { patients }\end{array}$ \\
\hline $\begin{array}{l}\text { Fraunberger } \\
\text { et al. [30] }\end{array}$ & $38 \mathrm{ICU}$ patients at the onset of fever & $\begin{array}{l}\text { (i) Increase in CRP at the onset of } \\
\text { fever } \\
\text { (ii) No difference between survivors } \\
\text { and nonsurvivors }\end{array}$ & $\begin{array}{l}\text { Comparisons of CRP between ICU } \\
\text { patients and volunteers }\end{array}$ \\
\hline Su et al. [31] & $\begin{array}{l}144 \text { ICU patients at the onset of } \\
\text { fever ( } 84 \text { sepsis and } 64 \text { SIRS) }\end{array}$ & $\begin{array}{l}\text { (i) CRP more elevated in septic } \\
\text { compared to patients with SIRS } \\
\text { (ii) CRP increase at the onset of } \\
\text { fever and could discriminate } \\
\text { patients with or without bacteremia }\end{array}$ & $\begin{array}{l}\text { CRP concentrations were lower in } \\
\text { patients with bacteremia }\end{array}$ \\
\hline $\begin{array}{l}\text { Christ-Crain } \\
\text { et al. [32] }\end{array}$ & $\begin{array}{l}50 \text { infected patients with }(n=24) \text { or } \\
\text { without appropriate antibiotics } \\
(n=18) \text { or peritonitis }(n=8)\end{array}$ & $\begin{array}{l}\text { An increase in CRP of at least } \\
2.2 \mathrm{mg} / \mathrm{dL} \text { in the first } 48 \mathrm{~h} \text { was } \\
\text { associated with ineffective initial } \\
\text { antibiotic therapy }\end{array}$ & $\begin{array}{l}\text { (i) Only } 8 \text { patients with peritonitis } \\
\text { (ii) No data on the timing of } \\
\text { reintervention }\end{array}$ \\
\hline
\end{tabular}


TABle 1: Continued.

\begin{tabular}{llll}
\hline Studies & Types of patients included & Conclusions & Remarks \\
\hline Bota et al. [33] & $\begin{array}{l}\text { (i) CRP levels were higher in } \\
\text { cirrhotic with infection compared to } \\
\text { without cirrhosis }(n=785)\end{array}$ & $\begin{array}{l}\text { No data about CRP levels in relation } \\
\text { with the severity of sepsis }(\mathrm{SOFA}, \\
\text { (ii) No difference related to severity } \\
\text { of the cirrhosis assessed } \\
\text { by the Child-Pugh classification. }\end{array}$ & $\begin{array}{l}\text { vasopress dosage, PaO } \mathrm{F}_{2} / \mathrm{FiO}_{2}, \\
\text { extra renal replacement) for each } \\
\text { level of cirrhosis }\end{array}$ \\
\hline $\begin{array}{l}\text { Silvestre et al. } \\
{[34]}\end{array}$ & 7 patients with hepatic failure & $\begin{array}{l}\text { Low CRP levels in patients with } \\
\text { infection }\end{array}$ & $\begin{array}{l}\text { Few patients included. One with a } \\
\text { diagnosis of hepatic failure at ICU } \\
\text { day 26 }\end{array}$ \\
\hline
\end{tabular}

authors observed a significantly higher CRP concentration in infected $(n=76)$ versus noninfected patients $(n=36)$. CRP values correlated well with the severity of the infection. For a cut-off of $8.7 \mathrm{mg} / \mathrm{dL}$, the sensitivity and specificity of CRP for a diagnosis of infection were 93.4 and $86.1 \%$, respectively. The specificity increased to $100 \%$ if CRP was combined with a temperature $>38.2^{\circ} \mathrm{C}$. Regrettably, the protocol of this study is difficult to transpose to the clinical situation. Indeed, the CRP concentrations included in the study for the nonseptic group were the values measured after 2 days of ICU stay and were compared to the leukocyte count and temperature on the day of ICU admission [20]. The same group [21] validated this CRP cut-off as a predictor of infection in a prospective study. They studied a very limited number of infected patients $(n=35)$ because only patients with a delay of 5 days between positive microbiological cultures and start of antibiotics were included. Patients with this cut-off of $8.7 \mathrm{mg} / \mathrm{dL}$ associated with a daily variation in CRP $>4.1 \mathrm{mg} / \mathrm{dL}$ had an $88 \%$ risk of infection [21].

In a prospective monocenter study, Lobo et al. [22] stratified 303 consecutive patients admitted to the ICU for a minimum of 48 hours according to the CRP concentration at ICU admission $(<1$, between $1-10$ and $>10 \mathrm{mg} / \mathrm{dL})$. They observed that CRP concentration at ICU admission was associated with organ dysfunction, ICU length of stay, and mortality. A CRP concentration $>10 \mathrm{mg} / \mathrm{dL}$ was associated with proven infection in $73 \%$ of the patients as compared to $31 \%$ when the CRP was $<1 \mathrm{mg} / \mathrm{dL}$ [22]. The time course of CRP concentrations also provided some interesting insights in the patients with high CRP concentrations $(>10 \mathrm{mg} / \mathrm{dL})$. A decreasing concentration in the first 48 hours was associated with a mortality of $15.4 \%$, whereas mortality reached $60.9 \%$ for patients in whom the CRP concentration increased (RR 0.25, CI: $0.07-0.97 ; P<0.05$ ) [22]. A study by Castelli et al. [23] provided similar results, but the results were not confirmed in a study by Silvestre et al. [24] In the study by Castelli et al. [23], the authors compared CRP concentrations in 255 patients (111 septic, 49 trauma, 45 with and 50 without systemic inflammatory response syndrome [SIRS]) observed for a total of 1826 days [23]. The best cut-off value of CRP concentration for diagnosis of sepsis was $12.8 \mathrm{mg} / \mathrm{dL}$, and these authors also reported a delay of 48 hours to reach the maximum CRP value. In the study by Silvestre et al. [24], which included 158 septic patients, the authors observed no significant differences in
CRP concentrations at ICU admission between survivors and nonsurvivors ( $25.3 \pm 13.7$ versus $28.2 \pm 13.2 \mathrm{mg} / \mathrm{dL})$, although the SOFA score was higher in nonsurvivors (Sequential Organ Failure Assessment-SOFA-Score [70]: $11 \pm 4$ versus $7 \pm 3, P<0.001)$. Moreover, the ICU mortality rates of septic patients with CRP concentrations $<10,10-20,20-30,30-40$ and $>40 \mathrm{mg} / \mathrm{dL}$ were $20 \%, 34 \%, 30.8 \%, 42.3 \%$, and $39.1 \%$, respectively, $P=0.7$, and the area under the curve for CRP to diagnose an infection was $0.55(0.45-0.65)$, no better than leukocyte count or temperature. Restricting the analysis to include only patients with microbiological proof of infection did not alter these findings [24].

Confirming that the time course of CRP concentrations is more important than a single admission value, Póvoa et al. [25] observed no significant differences between CRP in survivors and nonsurvivors until day 2 of antibiotic therapy in a multicenter prospective observational study including 891 septic patients. On the subsequent three days, the CRP concentration in survivors was significantly lower $(P<$ 0.001) than that of nonsurvivors. After adjusting for the Simplified Acute Physiology Score II and severity of sepsis, CRP time course was significantly associated with ICU mortality $(\mathrm{OR}=1.03$, CI 95\% 1.02-1.04, $P<0.001)$. The hospital mortality rates of patients with fast response, slow response, and no response patterns were 23, 30, and $41 \%$, respectively, $P=0.001$. Nonresponders had a significant increase in the odds of death $(\mathrm{OR}=2.5$, CI 95\% 1.6-4.0, $P<0.001)$ when compared with fast responders [25].

Two studies specifically reported a relationship between bacteremia and CRP concentrations (Table 1). Vandijck et al. [26] observed a relationship between the presence of Gramnegative bacteremia in $48 \mathrm{ICU}$ patients and variation in CRP concentrations of $5 \mathrm{mg} / \mathrm{dL}$ between 2 days prior to and the day after the onset of bacteremia [26]. Also in bacteremia, Póvoa et al. [27] suggested the importance of daily measurement of CRP concentrations in the assessment of appropriate antibiotherapy. Although body temperature and leukocyte counts were not significantly different in survivors and nonsurvivors in 44 patients with bacteremia, the ratio of CRP concentrations on the day measured and at admission did not change in nonsurvivors in contrast to survivors in whom changes were observed already at day 2 . Nevertheless, it was necessary to wait until day 4 to observe a relationship of the ratio with outcome [27]. This observation was also suggested in the meta-analysis of Zhang and Ni [28]. 
This meta-analysis included 1969 patients from 14 studies with large heterogeneity $\left(I^{2}=92 \%\right)$ and showed that the variation in CRP could be associated with mortality only after 48 hours.

CRP concentrations can also be used as a marker of infection in neutropenic patients. Póvoa et al. [29] compared body temperature, leukocyte count, and CRP concentrations in septic neutropenic and nonneutropenic patients admitted to the ICU (Table 1). There were no differences in core temperature between the 2 groups at admission, but higher concentrations of CRP were observed in neutropenic than in nonneutropenic patients. Among the neutropenic patients, CRP concentrations at ICU admission were not influenced by the severity of neutropenia. Nevertheless, white blood cell count was weakly correlated with CRP for all patients $(r=$ $0.25, P=0.012$ ). However, although severity scores and mortality rates were similar among groups, infection site and use of specific treatments (e.g., noninvasive ventilation) were different, making interpretation of the results difficult [29].

In a limited number of patients, Fraunberger et al. [30] looked at the predictive value of CRP, PCT, and IL-6 for development of sepsis after the first incidence of fever in 38 critically ill patients. They observed no differences in CRP concentrations at the onset of fever between survivors and nonsurvivors and CRP concentrations had the lowest AUC for discriminating infection compared to the two other markers. Nevertheless, CRP concentrations were compared to those in volunteers and not to values before fever onset or at ICU admission. Moreover, few data about patient characteristics (e.g., length of the inflammatory process) were reported in the paper [30]. Recently, Su et al. [31] compared values of CRP, PCT, and soluble triggering receptor expressed on myeloid cells (sTREM)-1 at ICU admission and during a new fever episode in the first 48 hours of the ICU stay. As expected, all these biomarkers were more elevated at ICU admission in septic patients compared to patients with SIRS. The authors observed that only the CRP level at the onset of fever could discriminate patients with or without bacteremia [31]. Although CRP changes in fever seemed to be interesting to determine new onset infection, CRP concentration was significantly lower in patients with bacteremia than in those without $(9.6 \pm 6.5$ versus $13.2 \pm 8 \mathrm{mg} / \mathrm{dL}, P=0.03)$ [31].

The time course of CRP as a marker of appropriate treatment, as has been suggested for PCT $[32,71]$, and as a marker for the end of infection is of potential interest, although few studies have reported these aspects during sepsis. Schmit and Vincent [72] reported the time course of CRP in 50 septic patients with adequate $(n=24)$ or inadequate $(n=18)$ empiric antibiotherapy and in surgical patients who needed reoperation for uncontrolled infection $(n=8)$ [72]. As expected, CRP concentrations decreased faster during the first 48 hours when the antibiotherapy was adequate, but an increase in CRP concentration of a minimum of $2.2 \mathrm{mg} / \mathrm{dL}$ over the 48-hour period was predictive of inadequate antibiotherapy with a sensitivity of $77 \%$ and a specificity of $67 \%$ [72]. These results were identical if a longer delay between CRP measurements was used. The take-home message of this study was the need for at least two CRP measurements with a delay of 48 hours to estimate the appropriateness of antibiotherapy, as suggested by the meta-analysis from Zhang and $\mathrm{Ni}$ [28]. Another interesting aspect of this study was the time course of CRP in a surgical population with uncontrolled infection. Regrettably, the number of patients studied was limited $(n=$ 8 ), and the delay for reoperation in case of uncontrolled infections was not reported, limiting the conclusions that can be drawn regarding the usefulness of CRP values in this particular population [72]. Further studies looking at the time course of CRP in relation to the need for reoperation and outcome are needed. Comparison of the time course of CRP values in relation to etiologies of sepsis (e.g., peritonitis versus pneumonia) may also be interesting.

In summary, diagnosis of infection in ICU patients remains difficult. One CRP value is probably not sufficient to discriminate infected from noninfected patients. The CRP ratio, already at day 2 but certainly at day 4 , is more predictive of infection and/or adequate antibiotherapy than individual values.

5.1. CRP Concentrations in Pneumonia. These studies included patients with ventilator-associated pneumonia (VAP) or community-acquired pneumonia (CAP) requiring ICU admission (Table 2). A majority of these patients received specific treatments for their condition, notably corticosteroids, and the effects of these agents on CRP are controversial $[67,68]$. In a subgroup of 48 patients with VAP, Póvoa et al. reported higher CRP concentrations but also core temperatures in infected than in noninfected patients. In contrast, leukocyte counts were not different [19]. No relationship with mortality was reported. Regrettably, the CRP difference between patients with VAP and other septic patients was not calculated [19]. In another study that included 45 patients with VAP, Hillas et al. [35] observed no difference in CRP concentrations at VAP diagnosis between survivors and nonsurvivors, but an increase in CRP between days 1 and 7 increased the risk of developing septic shock. Nevertheless, an important issue when trying to use these results in the clinical situation is the long delay (7 days) needed to discriminate between survivors and nonsurvivors; indeed, it would be difficult to wait such a long time before adapting therapy (e.g., changing antibiotherapy) [35].

Seligman et al. [36] also reported no difference in admission CRP concentrations between survivors and nonsurvivors in patients with VAP $(P=0.77)$, but in a logistic regression model, a decrease in CRP between day 4 and day 0 was associated with a favorable outcome (odds ratio $7.4(95 \%$ CI: 1.58-34.73). These correlations were also found for procalcitonin [36]. Similarly, Póvoa et al. [37] noted the importance of delta CRP between day 4 and admission in 47 patients with VAP. By day 4, a CRP of 0.6 times the initial level was a marker of poor outcome (sensitivity 0.92; specificity 0.59 ). All patients with fast and slow CRP concentration response patterns survived, whereas those showing no response and a biphasic response pattern exhibited a mortality of 78 and $75 \%$, respectively [37].

In two studies, one retrospective and monocenter [38] and the second prospective and multicenter [39], Coelho et al. 
TABLE 2: Summary of the studies in ICU patients with community-acquired (CAP) or ventilator-associated pneumonia (VAP).

\begin{tabular}{|c|c|c|c|}
\hline Studies & $\begin{array}{l}\text { Types of patients } \\
\text { included }\end{array}$ & Conclusions & Remarks \\
\hline Póvoa et al. [20] & $\begin{array}{l}48 \text { patients with } \\
\text { VAP }\end{array}$ & $\begin{array}{l}\text { CRP levels were higher than in } \\
\text { noninfected patients. }\end{array}$ & $\begin{array}{l}\text { (i) No relationship with mortality was reported. } \\
\text { (ii) No comparisons of CRP between patients with } \\
\text { VAP compared to other infections }\end{array}$ \\
\hline Hillas et al. [35] & $\begin{array}{l}45 \text { patients with } \\
\text { VAP }\end{array}$ & $\begin{array}{l}\text { (i) No difference in CRP concentrations } \\
\text { at VAP diagnosis between survivors and } \\
\text { nonsurvivors } \\
\text { (ii) Increase in CRP between days } 1 \text { and } 7 \\
\text { increased the risk of developing septic } \\
\text { shock }\end{array}$ & $\begin{array}{l}\text { Long delay ( } 7 \text { days) for the diagnosis of } \\
\text { inappropriate antibiotherapy }\end{array}$ \\
\hline
\end{tabular}
shock

\begin{tabular}{lcl}
$\begin{array}{l}\text { Seligman et al. } \\
\text { [36] }\end{array}$ & $\begin{array}{l}75 \text { patients with } \\
\text { VAP }\end{array}$ & $\begin{array}{l}\text { (ii) Decreased delta CRP between day } 4 \\
\text { to } 0 \text { was associated with survival }\end{array}$ \\
\hline Póvoa et al. [37] & $\begin{array}{c}\text { batients with } \\
\text { VAP }\end{array}$ & $\begin{array}{l}\text { By day 4, a CRP of } 0.6 \text { times the initial } \\
\text { level was a marker of poor outcome }\end{array}$ \\
\hline
\end{tabular}

\begin{tabular}{ccl} 
Coelho et al. [38] & $\begin{array}{c}\text { patients with } \\
\text { CAP }\end{array}$ & $\begin{array}{l}\text { By day } 3 \text { a CRP level } 0.5 \text { times the initial } \\
\text { level was a marker of poor outcome }\end{array}$ \\
\hline
\end{tabular}

\begin{tabular}{cc}
\hline & \\
& 191 patients with \\
Coelho et al. [39] & CAP, with \\
mechanical \\
ventilation
\end{tabular}

177 patients with
ARDS/ALI
(i) No difference in CRP levels at
admission between survivors and non-survivors
(ii) CRP ratio (Day 7/Day 1 ) decreased
significantly more rapidly in survivors

\section{(i) Lower CRP concentrations in non} survivors compared to survivors (ii) Difference in CRP was observed in patients with pneumonia but not in trauma patients

\section{Good correlation between the first}

Lisboa et al. [41]

68 ICU patients with VAP bacterial load and CRP concentrations and between variations of bacterial load and CRP over time

A decline of LESS than 60\% in CRP levels
289 patients with

Bruns et al. [42]

CAP, 137 with bacterial etiology in 3 days and a decline of LESS of $90 \%$ in CRP levels in 7 days were both associated with an increased risk of having received inappropriate empiric antibiotic treatment

(i) CRP levels were higher in patients with CAP with an isolated microorganism than without

Menendez et al. $\quad 658$ patients with (ii) CRP levels were significantly higher if CAP was associated with bacteremia (iii) No really great differences appears for CRP in relation to the type of causal microorganisms
No difference in outcome between patients with appropriate and inappropriate antibiotherapy
Importance of the CRP patterns at day 4 on outcome (fast response, nonresponse or biphasic response)

Importance of the CRP patterns at day 3 on outcome (fast response, nonresponse or biphasic response)

(i) Already at day 5, a CRP of above 0.5 of the baseline value was associated with a poor outcome.

(ii) Same results for patients with CAP with mechanical ventilation.

Nonsurvivors who had a higher APACHE 3 score and were older and more cirrhotic were included in this group

(i) Relationship between bacterial burden and CRP

(ii) A CRP ratio of 0.8 at 96 hours seems to be a useful indicator of adequate antibiotherapy

Importance of the CRP patterns at days 3 and 5 on outcome (fast response, nonresponse, or biphasic response)

Relation between causal microorganisms and CRP microorganisms

investigated the time course of CRP concentrations in ICU patients admitted for CAP. These authors defined several patterns in relation to the time course of CRP between the value at admission and that at days 5 and 7. Again, although CRP concentrations were not different between survivors and nonsurvivors at ICU admission, the CRP ratio (Day 7/Dayl) decreased significantly more rapidly in survivors. Already at day 5, a CRP of more than $0.5 \mathrm{mg} / \mathrm{dL}$ above the baseline value was associated with a poor outcome. Mortality rates for all patients were correlated to the CRP patterns described [38]. In the largest study [39], the authors specifically analyzed the subgroup of mechanically ventilated patients $(n=111)$ 
and also showed different patterns of CRP between survivors and nonsurvivors.

In contrast, Bajwa et al. [40], observed a lower CRP concentration in nonsurvivors $(n=70,176.5 \mathrm{mg} / \mathrm{L}$ (IQR, $173.0)$ ) compared to survivors $(n=107$, median $133.5 \mathrm{mg} / \mathrm{L}$, IQR, 161.0; $P=0.02$ ) in critically ill patients with acute respiratory distress syndrome/acute lung injury (ARDS/ALI). This difference in CRP was observed in patients with pneumonia but not in trauma patients [40]. For these authors, the results suggested a protective role of CRP by inhibiting neutrophil chemotaxis or modulating vascular permeability. Nevertheless, these results may be limited by the fact that nonsurvivors had greater APACHE III scores, were older, and included more cirrhotic patients who perhaps were less able to synthesis CRP [40].

CRP may also be a marker of bacterial load and appropriate antibiotherapy in these patients. Indeed, Lisboa et al. [41] investigated the correlation at days 1 and 4 between quantitative tracheal aspirate and CRP concentrations in 68 patients with VAP. They observed a good correlation between the first bacterial load and CRP concentrations $\left(r^{2}=0.46\right.$, $P<0.05)$ but also between variations in bacterial load and CRP over time $\left(r^{2}=0.59, P<0.05\right)$. A CRP ratio of 0.8 at 96 hours seemed to be a useful indicator of adequate antibiotherapy [41]. In less severely ill patients admitted for CAP, Bruns et al. [42] (Table 2) also observed this relationship between the time course of CRP and appropriate empiric antibiotherapy.

Recently, Menendez et al. [43] reviewed the values of several inflammatory biomarkers (CRP, procalcitonin, TNF$\alpha$, IL- $1 \beta$, IL-6, IL-8, IL-10) in relation to the microorganisms responsible for CAP. CRP levels were higher in patients with CAP with an isolated microorganism than those without (18.10 (9.70-27.30) versus $13.70(6.95-21.85) \mathrm{mg} / \mathrm{dL}, P=$ 0.002). CRP concentrations were significantly higher if CAP was associated with bacteremia (23.3 (14.9-35.1) versus 16.1 (8.8-24.1) $\mathrm{mg} / \mathrm{dL})$. In contrast, there were no major differences in CRP concentrations in relation to the type of causal microorganism (atypical pathogen, viruses, Gram-positive cocci, and Gram-negative bacilli) [43].

5.2. CRP Concentrations in Patients with Hepatic Failure. Because CRP is synthesized in the liver, it may be interesting to study its production in hepatic failure, a frequently observed disease in ICU patients, which shares some clinical aspects with the septic process [73]. Bota et al. compared CRP and PCT concentrations in 864 patients with $(n=79)$ and without cirrhosis $(n=785)$ [33]. CRP concentrations were higher in cirrhotic patients with infection compared to cirrhotic patients without infection. These authors did not observe any difference related to the severity of the cirrhosis as assessed by the Child-Pugh classification [33]. However, CRP concentrations in relation to the severity of sepsis (SOFA, vasopressor dosage, $\mathrm{PaO}_{2} / \mathrm{FiO}_{2}$, renal replacement therapy) for each level of cirrhosis were not reported [33]. In other words, could a cirrhotic patient with Child-Pugh $\mathrm{C}$ cirrhosis increase CRP concentrations in the same way as a Child Pugh A cirrhotic patient for the same level of sepsis severity? Probably not, and this suggestion is perhaps supported by results from a study by Silvestre et al. [34] in 7 patients admitted for hepatic failure with sepsis. The authors reported very low concentrations of CRP despite proven infection and suggested choosing a biomarker other than CRP in these particular patients.

\section{Conclusion}

In conclusion, the diagnosis of infection is based on a set of factors, including clinical history, semiology, and clinical and hemodynamic parameters. CRP concentration, with its rapid and cheap measurement, may be a good partner to refine the diagnosis of infection. The time course of CRP concentrations, already at 48 hours, but more interesting at day 4 , is of more use than a single measure. Despite daily measurement of CRP in ICUs worldwide, data are relatively limited and studies with more patients, looking at the time course in relation to the etiologies of infection, to the severity and to treatment effects (e.g., of glucocorticoids or statins) are needed to confirm the usefulness of CRP to discriminate infected from noninfected critically ill patients.

\section{Conflict of Interests}

The authors declare that they have no conflict of interests.

\section{References}

[1] D. C. Angus, W. T. Linde-Zwirble, J. Lidicker, G. Clermont, J. Carcillo, and M. R. Pinsky, "Epidemiology of severe sepsis in the United States: analysis of incidence, outcome, and associated costs of care," Critical Care Medicine, vol. 29, no. 7, pp. 1303-1310, 2001.

[2] G. Kumar, N. Kumar, A. Taneja et al., "Nationwide trends of severe sepsis in the 21st century (2000-2007)," Chest, vol. 140, no. 5, pp. 1223-1231, 2011.

[3] J. L. Vincent, Y. Sakr, C. L. Sprung et al., "Sepsis in European intensive care units: results of the SOAP study," Critical Care Medicine, vol. 34, no. 2, pp. 344-353, 2006.

[4] J. L. Vincent, J. Rello, J. Marshall et al., "International study of the prevalence and outcomes of infection in intensive care units," Journal of the American Medical Association, vol. 302, no. 21, pp. 2323-2329, 2009.

[5] J. L. Vincent, E. Abraham, D. Annane, G. Bernard, E. Rivers, and G. Van den Berghe, "Reducing mortality in sepsis: new directions," Critical Care, vol. 6, supplement 3, pp. S1-S18, 2002.

[6] Emerging Risk factors collaboration, S. Kaptoge, E. Di Angelantonio et al., "C-reactive protein, fibrinogen, and cardiovascular disease prediction," The New England Journal of Medicine, vol. 367, no. 14, pp. 1310-1320, 2012.

[7] M. B. Pepys and G. M. Hirschfield, "C-reactive protein: a critical update," Journal of Clinical Investigation, vol. 111, no. 12, pp. 1805-1812, 2003.

[8] B. Molins, E. Peña, G. Vilahur, C. Mendieta, M. Slevin, and L. Badimon, "C-reactive protein isoforms differ in their effects on thrombus growth," Arteriosclerosis, Thrombosis, and Vascular Biology, vol. 28, no. 12, pp. 2239-2246, 2008. 
[9] W. S. Tillet and T. Francis, "Serological reactions in pneumonia with a non-protein somatic fraction of pneumococcus," Journal of Experimental Medicine, vol. 52, no. 4, pp. 561-571, 1930.

[10] B. Shine, F. C. de Beer, and M. B. Pepys, "Solid phase radioimmunoassays for human C-reactive protein," Clinica Chimica Acta, vol. 117, no. 1, pp. 13-23, 1981.

[11] S. G. Lakoski, M. Cushman, M. Criqui et al., "Gender and Creactive protein: data from the Multiethnic Study of Atherosclerosis (MESA) cohort," American Heart Journal, vol. 152, no. 3, pp. 593-598, 2006.

[12] A. Pfäfflin and E. Schleicher, "Inflammation markers in pointof-care testing (POCT)," Analytical and Bioanalytical Chemistry, vol. 393, no. 5, pp. 1473-1480, 2009.

[13] D. M. Vigushin, M. B. Pepys, and P. N. Hawkins, "Metabolic and scintigraphic studies of radioiodinated human C-reactive protein in health and disease," Journal of Clinical Investigation, vol. 91, no. 4, pp. 1351-1357, 1993.

[14] W. M. Juma, A. Lira, A. Marzuk, Z. Marzuk, A. M. Hakim, and C. S. Thompson, "C-reactive protein expression in a rodent model of chronic cerebral hypoperfusion," Brain Research, vol. 1414, pp. 85-93, 2011.

[15] M. Meuwissen, A. C. van der Wal, H. W. M. Niessen et al., "Colocalisation of intraplaque $\mathrm{C}$ reactive protein, complement, oxidised low density lipoprotein, and macrophages in stable and unstable angina and acute myocardial infarction," Journal of Clinical Pathology, vol. 59, no. 2, pp. 196-201, 2006.

[16] A. E. Kuta and L. L. Baum, "C-reactive protein is produced by a small number of normal human peripheral blood lymphocytes," Journal of Experimental Medicine, vol. 164, no. 1, pp. 321-326, 1986.

[17] P. Calabro, D. W. Chang, J. T. Willerson, and E. T. H. Yeh, "Release of C-reactive protein in response to inflammatory cytokines by human adipocytes: linking obesity to vascular inflammation," Journal of the American College of Cardiology, vol. 46, no. 6, pp. 1112-1113, 2005.

[18] H. Ugarte, E. Silva, D. Mercan, A. de Mendonca, and J. Vincent, "Procalcitonin used as a marker of infection in the intensive care unit," Critical Care Medicine, vol. 27, no. 3, pp. 498-504, 1999.

[19] J. L. Reny, A. Vuagnat, C. Ract, M. O. Benoit, M. Safar, and J. Fagon, "Diagnosis and follow-up of infections in intensive care patients: value of C-reactive protein compared with other clinical and biological variables," Critical Care Medicine, vol. 30, no. 3, pp. 529-535, 2002.

[20] P. Póvoa, L. Coelho, E. Almeida et al., "C-reactive protein as a marker of infection in critically ill patients," Clinical Microbiology and Infection, vol. 11, no. 2, pp. 101-108, 2005.

[21] P. Póvoa, L. Coelho, E. Almeida et al., "Early identification of intensive care unit-acquired infections with daily monitoring of C-reactive protein: a prospective observational study," Critical Care, vol. 10, no. 2, p. R63, 2006.

[22] S. M. Lobo, F. R. Lobo, D. P. Bota et al., "C-reactive protein levels correlate with mortality and organ failure in critically III patients," Chest, vol. 123, no. 6, pp. 2043-2049, 2003.

[23] G. P. Castelli, C. Pognani, M. Cita, A. Stuani, L. Sgarbi, and R. Paladini, "Procalcitonin, C-reactive protein, white blood cells and SOFA score in ICU: diagnosis and monitoring of sepsis," Minerva Anestesiologica, vol. 72, no. 1-2, pp. 69-80, 2006.

[24] J. Silvestre, P. Póvoa, L. Coelho et al., "Is C-reactive protein a good prognostic marker in septic patients?" Intensive Care Medicine, vol. 35, no. 5, pp. 909-913, 2009.
[25] P. Póvoa, A. M. Teixeira-Pinto, and A. H. Carneiro, "C-reactive protein, an early marker of community-acquired sepsis resolution: a multi-center prospective observational study," Critical Care, vol. 15, no. 4, p. R169, 2011.

[26] D. M. Vandijck, E. A. Hoste, S. I. Blot, P. O. Depuydt, R. A. Peleman, and J. M. Decruyenaere, "Dynamics of C-reactive protein and white blood cell count in critically ill patients with nosocomial Gram positive vs. Gram negative bacteremia: a historical cohort study," BMC Infectious Diseases, vol. 7, p. 106, 2007.

[27] P. Póvoa, L. Coelho, E. Almeida et al., "Pilot study evaluating C-reactive protein levels in the assessment of response to treatment of severe bloodstream infection," Clinical Infectious Diseases, vol. 40, no. 12, pp. 1855-1857, 2005.

[28] Z. Zhang and H. Ni, "C-reactive protein as a predictor of mortality in critically ill patients: a meta-analysis and systematic review," Anaesthesia and Intensive Care, vol. 39, no. 5, pp. 854861, 2011.

[29] P. Póvoa, V. C. Souza-Dantas, M. Soares, and J. I. F. Salluh, "C-reactive protein in critically ill cancer patients with sepsis: influence of neutropenia," Critical Care, vol. 15, no. 3, p. R129, 2011.

[30] P. Fraunberger, Y. Wang, E. Holler et al., "Prognostic value of interleukin 6, procalcitonin, and C-reactive protein levels in intensive care unit patients during first increase of fever," Shock, vol. 26, no. 1, pp. 10-12, 2006.

[31] L. Su, B. Han, C. Liu et al., "Value of soluble TREM-1, procalcitonin and C-reactive protein serum levels as biomarkers for detecting bacteremia among sepsis patients with new fever in intensive care units: a prospective cohort study," BMC Infectious Diseases, vol. 12, p. 157, 2012.

[32] M. Christ-Crain, D. Jaccard-Stolz, R. Bingisser et al., "Effect of procalcitonin-guided treatment on antibiotic use and outcome in lower respiratory tract infections: cluster-randomised, single-blinded intervention trial," The Lancet, vol. 363, no. 9409, pp. 600-607, 2004.

[33] D. Peres Bota, M. Van Nuffelen, A. N. Zakariah, and J. Vincent, "Serum levels of C-reactive protein and procalcitonin in critically ill patients with cirrhosis of the liver," Journal of Laboratory and Clinical Medicine, vol. 146, no. 6, pp. 347-351, 2005.

[34] J. P. Silvestre, L. M. Coehlo, and P. M. Povoa, "Impact of fulminant hepatic failure in C-reactive protein?" Journal of Critical Care, vol. 25, no. 4, pp. 657.e7-657.12, 2010.

[35] G. Hillas, T. Vassilakopoulos, P. Plantza, A. Rasidakis, and P. Bakakos, "C-reactive protein and procalcitonin as predictors of survival and septic shock in ventilator-associated pneumonia," European Respiratory Journal, vol. 35, no. 4, pp. 805-811, 2010.

[36] R. Seligman, M. Meisner, T. C. Lisboa et al., "Decreases in procalcitonin and C-reactive protein are strong predictors of survival in ventilator-associated pneumonia," Critical Care, vol. 10, no. 5, p. R125, 2006.

[37] P. Póvoa, L. Coelho, E. Almeida et al., "C-reactive protein as a marker of ventilator-associated penumonia resolution: a pilot study," European Respiratory Journal, vol. 25, no. 5, pp. 804-812, 2005.

[38] L. Coelho, P. Póvoa, E. Almeida et al., "Usefulness of Creactive protein in monitoring the severe community-acquired pneumonia clinical course," Critical Care, vol. 11, p. R92, 2007.

[39] L. M. Coelho, J. I. Salluh, M. Soares et al., "Patterns of Creactive protein ratio response in severe community-acquired pneumonia: a cohort study," Critical Care, vol. 16, p. R53, 2012. 
[40] E. K. Bajwa, U. A. Khan, J. L. Januzzi, M. N. Gong, B. T. Thompson, and D. C. Christiani, "Plasma C-reactive protein levels are associated with improved outcome in ARDS," Chest, vol. 136, no. 2, pp. 471-480, 2009.

[41] T. C. Lisboa, R. Seligman, E. Diaz, A. Rodriguez, P. J. Z. Teixeira, and J. Rello, "C-reactive protein correlates with bacterial load and appropriate antibiotic therapy in suspected ventilatorassociated pneumonia," Critical Care Medicine, vol. 36, no. 1, pp. 166-171, 2008.

[42] A. H. W. Bruns, J. J. Oosterheert, E. Hak, and A. I. M. Hoepelman, "Usefulness of consecutive C-reactive protein measurements in follow-up of severe community-acquired pneumonia," European Respiratory Journal, vol. 32, no. 3, pp. 726-732, 2008.

[43] R. Menendez, J. M. Sahuquillo-Arce, S. Reyes et al., "Cytokine activation patterns and biomarkers are influenced by microorganisms in community-acquired pneumonia," Chest, vol. 141, no. 6, pp. 1537-1545, 2012.

[44] I. F. Rowe, A. K. Soutar, and I. M. Trayner, "Rabbit and rat C-reactive proteins bind apolipoprotein B-containing lipoproteins," Journal of Experimental Medicine, vol. 159, no. 2, pp. 604616, 1984.

[45] D. Gershov, S. Kim, N. Brot, and K. B. Elkon, "C-reactive protein binds to apoptotic cells, protects the cells from assembly of the terminal complement components, and sustains an antiinflammatory innate immune response: implications for systemic autoimmunity," Journal of Experimental Medicine, vol. 192, no. 9, pp. 1353-1363, 2000.

[46] D. Thomas-Rudolph, T. W. Du Clos, C. M. Snapper, and C. Mold, "C-reactive protein enhances immunity to Streptococcus pneumoniae by targeting uptake to $\mathrm{F} c \gamma \mathrm{R}$ on dendritic cells," Journal of Immunology, vol. 178, no. 11, pp. 7283-7291, 2007.

[47] A. Agrawal, A. K. Shrive, T. J. Greenhough, and J. E. Volanakis, "Topology and structure of the Clq-binding site on C-reactive protein," Journal of Immunology, vol. 166, no. 6, pp. 3998-4004, 2001.

[48] A. I. Okemefuna, R. Nan, A. Miller, J. Gor, and S. J. Perkins, "Complement factor $\mathrm{H}$ binds at two independent sites to $\mathrm{C}$ reactive protein in acute phase concentrations," Journal of Biological Chemistry, vol. 285, no. 2, pp. 1053-1065, 2010.

[49] J. Hellwage, T. S. Jokiranta, M. A. Friese et al., "Complement C3b/C3d and cell surface polyanions are recognized by overlapping binding sites on the most carboxyl-terminal domain of complement factor H," Journal of Immunology, vol. 169, no. 12, pp. 6935-6944, 2002.

[50] D. Xia and D. Samols, "Transgenic mice expressing rabbit Creactive protein are resistant to endotoxemia," Proceedings of the National Academy of Sciences of the United States of America, vol. 94, no. 6, pp. 2575-2580, 1997.

[51] S. U. Eisenhardt, J. R. Thiele, H. Bannasch, G. B. Stark, and K. Peter, "C-reactive protein: how conformational changes influence inflammatory properties," Cell Cycle, vol. 8, no. 23, pp. 3885-3892, 2009.

[52] Q. Wang, X. Zhu, Q. Xu, X. Ding, Y. E. Chen, and Q. Song, "Effect of C-reactive protein on gene expression in vascular endothelial cells," American Journal of Physiology, vol. 288, no. 4, pp. H1539-H1545, 2005.

[53] G. M. Hirschfield, J. Herbert, M. C. Kahan, and M. B. Pepys, "Human C-reactive protein does not protect against acute lipopolysaccharide challenge in mice," Journal of Immunology, vol. 171, no. 11, pp. 6046-6051, 2003.

[54] P. Cirillo, P. Golino, P. Calabrò et al., "C-reactive protein induces tissue factor expression and promotes smooth muscle and endothelial cell proliferation," Cardiovascular Research, vol. 68, no. 1, pp. 47-55, 2005.

[55] S. Devaraj, D. Y. Xu, and I. Jialal, "C-reactive protein increases plasminogen activator inhibitor-1 expression and activity in human aortic endothelial cells: implications for the metabolic syndrome and atherothrombosis," Circulation, vol. 107, no. 3, pp. 398-404, 2003.

[56] F. Fourrier, "Severe sepsis, coagulation and fibrinolysis: dead end or one way?" Critical Care Medicine, vol. 40, no. 9, pp. 27042708, 2012.

[57] R. J. Bisoendial, J. J. P. Kastelein, J. H. M. Levels et al., "Activation of inflammation and coagulation after infusion of C-reactive protein in humans," Circulation Research, vol. 96, no. 7, pp. 714716, 2005.

[58] R. J. Bisoendial, J. J. P. Kastelein, S. L. M. Peters et al., "Effects of CRP infusion on endothelial function and coagulation in normocholesterolemic and hypercholesterolemic subjects," Journal of Lipid Research, vol. 48, no. 4, pp. 952-960, 2007.

[59] M. B. Pepys, P. N. Hawkins, M. C. Kahan et al., "Proinflammatory effects of bacterial recombinant human $\mathrm{C}$-reactive protein are caused by contamination with bacterial products, not by Creactive protein itself," Circulation Research, vol. 97, no. 11, pp. e97-e103, 2005.

[60] K. Z. Boudjeltia, M. Piagnerelli, D. Brohée et al., "Relationship between CRP and hypofibrinolysis: is this a possible mechanism to explain the association between CRP and outcome in critically ill patients?” Thrombosis Journal, vol. 2, p. 7, 2004.

[61] E. Grad, M. Golomb, I. Mor-Yosef et al., “Transgenic expression of human C-reactive protein suppresses endothelial nitric oxide synthase expression and bioactivity after vascular injury," American Journal of Physiology, vol. 293, no. 1, pp. H489-H495, 2007.

[62] B. R. Clapp, G. M. Hirschfield, C. Storry et al., "Inflammation and endothelial function: direct vascular effects of human Creactive protein on nitric oxide bioavailability," Circulation, vol. 111, no. 12, pp. 1530-1536, 2005.

[63] J. Chen, J. Jin, M. Song, H. Dong, G. Zhao, and L. Huang, "C-reactive protein down-regulates endothelial nitric oxide synthase expression and promotes apoptosis in endothelial progenitor cells through receptor for advanced glycation endproducts," Gene, vol. 496, no. 2, pp. 128-135, 2012.

[64] H. Fujii, S. H. Li, P. E. Szmitko, P. W. M. Fedak, and S. Verma, "C-reactive protein alters antioxidant defenses and promotes apoptosis in endothelial progenitor cells," Arteriosclerosis, Thrombosis, and Vascular Biology, vol. 26, no. 11, pp. 2476-2482, 2006.

[65] A. Kumar, "Optimizing antimicrobial therapy in sepsis and septic shock," Critical Care Clinics, vol. 25, no. 4, pp. 733-751, 2009.

[66] C. Pierrakos and J. Vincent, "Sepsis biomarkers: a review," Critical Care, vol. 14, no. 1, p. R15, 2010.

[67] J. I. F. Salluh, L. S. C. F. Rabello, M. M. Rosolem et al., "The impact of coagulation parameters on the outcomes of patients with severe community-acquired pneumonia requiring intensive care unit admission," Journal of Critical Care, vol. 26, no. 5, pp. 496-501, 2011.

[68] A. Perren, B. Cerutti, M. Lepori et al., "Influence of steroids on Procalcitonin and C-reactive protein in patients with COPD and community-acquired pneumonia," Infection, vol. 36, no. 2, pp. 163-166, 2008. 
[69] P. M. Ridker and J. D. Silvertown, "Inflammation, C-reactive protein, and atherothrombosis," Journal of Periodontology, vol. 79, no. 8, pp. 1544-1551, 2008.

[70] J. L. Vincent, A. de Mendonça, F. Cantraine et al., "Use of the SOFA score to assess the incidence of organ dysfunction/failure in intensive care units: results of a multicenter, prospective study," Critical Care Medicine, vol. 26, no. 11, pp. 1793-1800, 1998.

[71] M. Hochreiter, T. Köhler, A. M. Schweiger et al., "Procalcitonin to guide duration of antibiotic therapy in intensive care patients: a randomized prospective controlled trial," Critical Care, vol. 13, no. 3, p. R83, 2009.

[72] X. Schmit and J. L. Vincent, "The time course of blood Creactive protein concentrations in relation to the response to initial antimicrobial therapy in patients with sepsis," Infection, vol. 36, no. 3, pp. 213-219, 2008.

[73] J. L. Vincent and T. Gustot, "Sepsis and cirrhosis: many similarities," Acta Gastro-Enterologica Belgica, vol. 73, no. 4, pp. 472-478, 2010. 


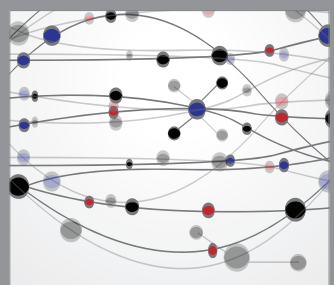

The Scientific World Journal
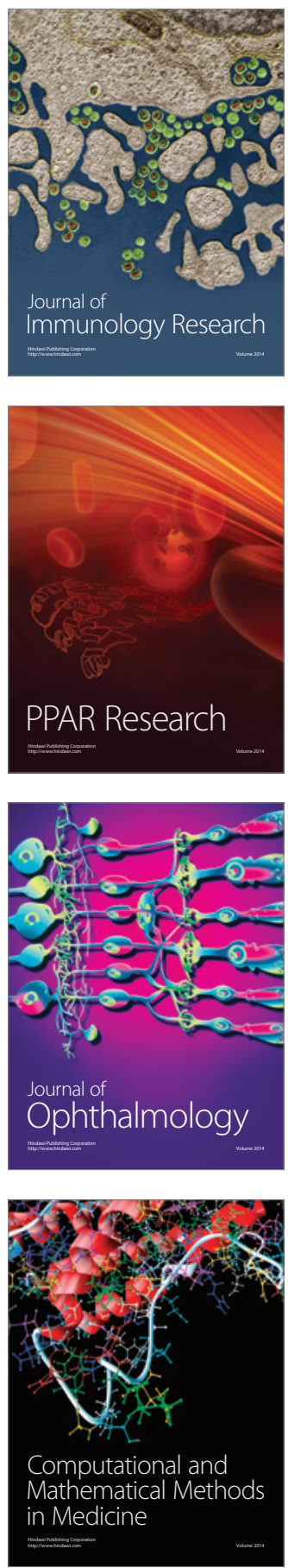

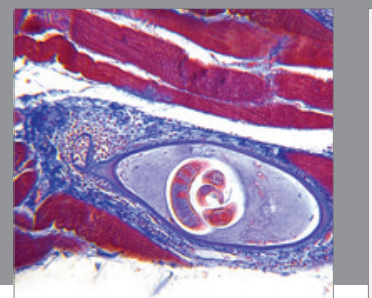

Gastroenterology

Research and Practice
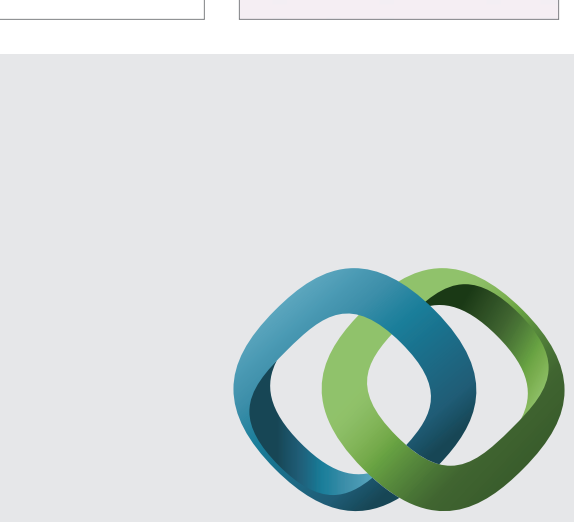

\section{Hindawi}

Submit your manuscripts at

http://www.hindawi.com
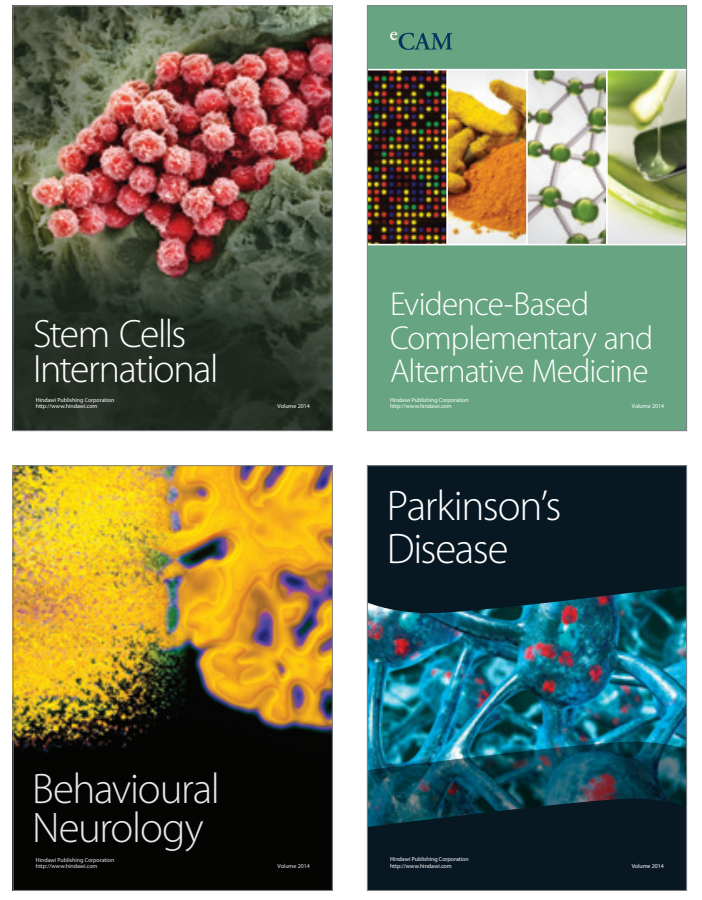
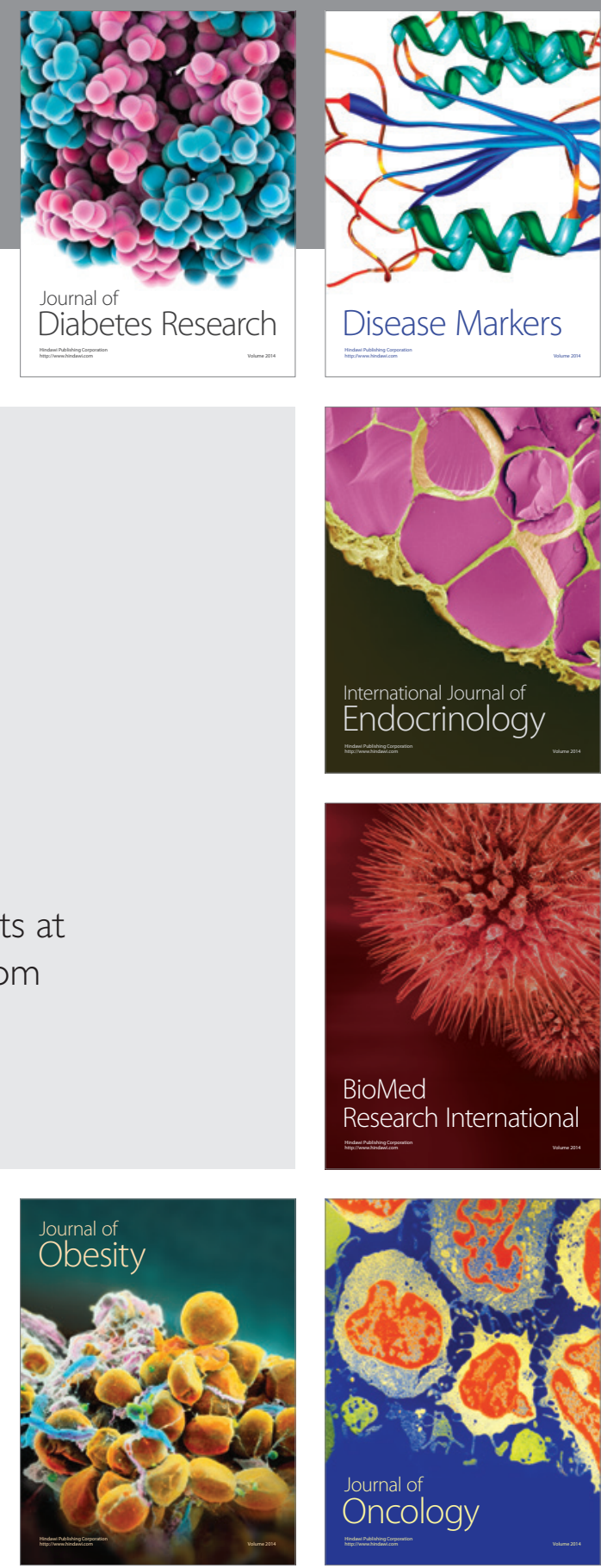

Disease Markers
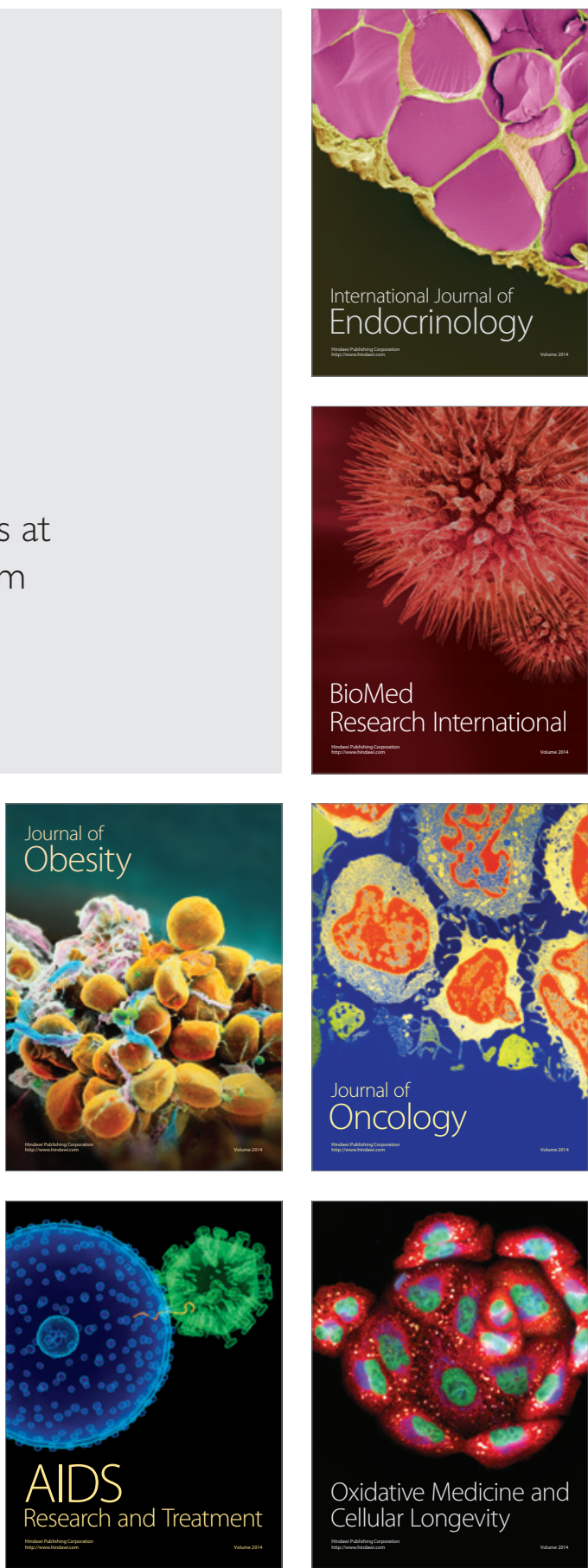